\title{
COMMUNICATIONS
}

\section{NOTES ON OPHTHALMOLOGICAL PRACTICE IN LUND*†}

\author{
BY \\ SVEN LARSSON \\ Lund, Sweden
}

LAST autumn when I was asked to address the Ophthalmological Section of the Royal Society of Medicine I was rather doubtful whether I should be able to present any really new research work. We have to do our research alongside strenuous routine work and I do not think that we shall be able to assert ourselves in this field until we have whole-time researchers attached to the clinic. I have therefore decided to talk about a few clinical problems, to which we have directed special attention during the last few years.

Cataract Extraction.-I cannot resist the temptation to dwell first on the operation for cataract, which is, and probably always will be, the operation in ophthalmology. The subject is just as fascinating to the ophthalmologist as the role of Hamlet to the actor. Every surgeon views the subject from his own angle and there are no two clinics that I have seen, where the operation is done by exactly the same technique. A few years ago we in Lund began to adopt an intracapsular operative method, which closely resembles that introduced by the Baltimore school.

I would, however, point out that the old extracapsular operation should not yet be rejected or regarded as old-fashioned; on the contrary, it is simpler and involves fewer risks. It seems contradictory to say that one method is more difficult than another and to claim at the same time that the attendant risks are not larger. Anyone who has taught young ophthalmologists how to operate for cataract will be able to confirm this. The intracapsular method is not an easy one for beginners. The question is whether less trained or less skilled surgeons should not be dissuaded from using it. Although I have regularly operated intracapsularly during recent years, I must agree with Ridley (1952), whose boldness cannot be questioned when it comes to trying new surgical methods, when he admits point blank the advantages of the extracapsular methods. On the other hand, I cannot agree with Knapp (1947), when he says at the end of his interesting report on the present status of the intracapsular cataract operation:

If you can establish a safe method of intracapsular cataract extraction, you will equal Daviel's contribution to humanity.

In my opinion, the intracapsular operation for cataract marks no such revolutionary advance, though I readily admit its advantages when performed by well-trained and experienced surgeons.

* Received for publication October 24, 1952.

+ Paper read to the Royal Society of Medicine in June, 1952. 
The main disadvantage of extracapsular operation seems to me to be that we cannot predict whether or not soft cataract matter will persist in a given case. If the occurrence of such residual matter could be obviated with certainty, I think that many would still prefer the extracapsular method.

The intracapsular method is technically difficult and in certain respects involves greater risks. The larger incision and the corneoscleral suture, so invaluable in intracapsular surgery, require still greater "aseptic precautions, because the application of the stitches undeniably and unavoidably increases the possibility of infection. The larger incision with its increased disturbance of the circulation and resultant poor blood supply to the resected corneal graft increases this risk still more.

The Baltimore school claim that the intracapsular method is not more risky as regards detachment than the extracapsular method, but anyone who sees the tremulous iris and the anteriorly often ill-defined vitreous body must fear this complication.

The extraordinary importance of surgically aseptic conditions is evident. We have recently made regular bacteriological examinations in all cases of cataract. Table I shows that pathogenic bacterial growth was found in a number of cases, even though the conjunctivae showed no signs of inflammation in 24 per cent.

TABLE I

CULTURES BEFORE OPERATION FOR CATARACT IN 597 CASES

\begin{tabular}{|c|c|c|c|c|c|}
\hline \multicolumn{3}{|l|}{ Bacteria } & Apathogenic & Pathogenic & Total \\
\hline \multicolumn{2}{|c|}{ Staphylococcus albus... } & $\ldots$ & 144 & 85 & 229 \\
\hline \multicolumn{2}{|c|}{ Staphylococcus aureus } & $\ldots$ & & 33 & 33 \\
\hline $\begin{array}{ll}\text { Streptococcus } & \\
\text { (a) } \alpha & \ldots \\
\text { (b) } \beta & \ldots \\
\text { (c) } & \text { viridans }\end{array}$ & $\begin{array}{l} \\
\cdots \\
\cdots \\
\cdots\end{array}$ & $\begin{array}{l}\cdots \\
\cdots \\
\cdots\end{array}$ & & $\begin{array}{l}8 \\
5 \\
2\end{array}$ & 15 \\
\hline $\begin{array}{l}\text { Pneumococcus } \\
\text { (a) type } 3 \\
\text { (b) type } 15 \\
\text {. } \ldots\end{array}$ & $\begin{array}{l}\ldots \\
\ldots\end{array}$ & $\begin{array}{ll}\ldots \\
\cdots \\
\cdots\end{array}$ & & $\begin{array}{l}1 \\
1\end{array}$ & 2 \\
\hline Enterococcus $\ldots$ & $\ldots$ & $\ldots$ & & 2 & 2 \\
\hline Bacillus xerosis & $\ldots$ & $\ldots$ & 51 & & 51 \\
\hline Bacterium coli... & $\ldots$ & $\ldots$ & & 4 & 4 \\
\hline Proteus vulgaris & $\ldots$ & $\ldots$ & & 1 & 1 \\
\hline Sarcina & $\ldots$ & $\ldots$ & 2 & & 2 \\
\hline Gaffyka tetragena & $\ldots$ & $\ldots$ & . & (1) & 1 \\
\hline Sterile ... & $\ldots$ & $\ldots$ & - & - & 257 \\
\hline $\begin{array}{ccc}\text { Total } & \ldots & \ldots\end{array}$ & $\ldots$ & $\ldots i$ & & 143 (24 per cent.) & 597 \\
\hline
\end{tabular}


After repeated treatment with sulphonamides or penicillin the bacterial growth disappeared, but even so we have had three cases of infection (Table II).

TABLE II

THREE CASES OF INFECTION IN 830 CATARACT EXTRACTIONS

\begin{tabular}{|c|c|c|c|c|c|c|c|}
\hline $\begin{array}{l}\text { Case } \\
\text { No. }\end{array}$ & Diagnosis & $\begin{array}{c}\text { Pre-operative } \\
\text { Culture }\end{array}$ & Operation & $\begin{array}{l}\text { Days after } \\
\text { Infection }\end{array}$ & $\begin{array}{l}\text { Post-operative } \\
\text { Culture }\end{array}$ & Result & Comment \\
\hline 1 & Cat. senilis & $\begin{array}{l}\text { Pneumococcus } \\
\text { type } 15\end{array}$ & $\begin{array}{l}\text { Combined } \\
\text { extracap- } \\
\text { sular ex- } \\
\text { traction }\end{array}$ & 1 & - & $\begin{array}{r}\text { Evisceration } \\
\text { after } 8 \text { days }\end{array}$ & \\
\hline 2 & $\begin{array}{l}\text { Cat. senilis } \\
+\underset{\text { Dia- }}{+} \\
\text { betes }\end{array}$ & $\begin{array}{l}\text { Apathogenic } \\
\text { staphylo- } \\
\text { coccus }\end{array}$ & $\begin{array}{l}\text { Combined } \\
\text { intracap- } \\
\text { sular ex- } \\
\text { traction }\end{array}$ & 1 & $\begin{array}{l}\text { 1. } 2 . \quad 3 .=P s . \\
\text { pyocyaneus }\end{array}$ & Phthisis bulbi & $\begin{array}{l}\text { The last eye. } \\
\text { The other eye } \\
\text { embolism of } \\
\text { the centr. ar- } \\
\text { tery }\end{array}$ \\
\hline 3 & $\begin{array}{l}\text { Cat. senilis } \\
+\underset{\text { Dia- }}{+} \\
\text { betes }\end{array}$ & - & $\begin{array}{l}\text { Combined } \\
\text { extracap- } \\
\text { sular ex- } \\
\text { traction }\end{array}$ & 2 & - & $\begin{array}{l}\text { Evisceration } \\
\text { after } 16 \\
\text { days }\end{array}$ & $\begin{array}{l}\text { Culture from } \\
\text { other eye } \\
\text { showed patho-- } \\
\text { genic staphy- } \\
\text { lococcus }\end{array}$ \\
\hline
\end{tabular}

(1) One case, which I still have on my conscience, illustrates the value of bacteriological examination. The patient was a 69 -year-old woman in whom the conjunctiva showed no signs of inflammation. For some personal reason or other I operated without waiting for the bacteriologist's report, and the third day after operation the wound showed an ugly inflammation which resulted in the loss of the eye. Too late we learned from the bacteriologist that the specimen taken from the conjunctiva one day before the operation contained pneumococci. Since then I have never operated without first receiving the bacteriologist's report. The second eye was operated on with success.

(2) Another case of infection, in which I think the sutures were the cause of the trouble, was that of a one-eyed 65-year-old woman. Clinical and bacteriological examination had revealed no signs of infection, and the eye had been couched intracapsularly without complications. On the third day after the operation, purulent discharge appeared round the stitches. Sulphonamides and antibiotics failed to arrest the infection, and bacteriological examination revealed infection with Ps. pyocyaneus. The only explanation we could find was that the micro-organisms had found their way to the eye by the sutures when they were passed through the skin, where pyocyaneus is sometimes present in otherwise healthy persons. Despite intensive medication we could not stop the damage and the eye was lost.

(3) The third case was that of a 75-year-old woman with diabetes. No bacteriological test was carried out and the eye was lost because of infection.

Even though these losses amounted to no more than three out of 830 operations, the fact that there is still a certain risk of infection must be borne in mind.

In the intracapsular method the pressure exerted by the muscles on the eyeball should be eliminated and the intra-ocular pressure should, when possible, be reduced. Akinesia should, of course, be carefully induced over the facial nerve; we make it both over the orbital margin and also in front of the external auditory meatus. (According to Paufique, 1952, a 96 per cent. solution of alcohol, $2 \mathrm{ml}$. for every $10 \mathrm{ml}$. novocain, increases the effect). Retrobulbar injection of novocain or the like with adrenaline has an analgesic 
effect and also decreases the power of the muscles to exert pressure against the eyeball, while the adrenaline reduces the intra-ocular pressure. An addition of hyaluronidase may be of value. Sometimes, but only rarely, the injection produces an increase instead of a decrease in the intra-ocular pressure. Nowadays I usually measure the pressure tonometrically 5 minutes after the injection, i.e., immediately before the operation, since experience has taught me that it is risky to operate, particularly intracapsularly, if the intra-ocular pressure is even slightly increased.

Hypermature Cataract is a type that has interested me very much, and one which we have seen fairly often at the clinic. This may be due to the fact that eye clinics in Sweden were formerly few and far between, and also to the mental make-up of the Swedes, in that many old people prefer puttingup with impaired vision to submitting to an operation.

It has long been known that this type of cataract, which has become increasingly rare and is now looked upon as a curiosity, can lead to complications. Of particular interest in this connection is acute glaucoma, often found in association with a more or less severe exudative iritis, and sometimes with hypopyon. These cases have sometimes been conceived as "panophthalmitis" with a secondary increase in intra-ocular pressure, but the cause of the clinical picture is still obscure. Knapp (1947) suggested that it was due to mechanical injury. Gifford (1927) suggested a chemical or toxic irritation in certain cases and occlusion of the angle of the chamber by cataract matter when the capsule ruptured. The idea of toxic action on the substance of the lenses is old; it was believed that the effect was due to amino-acids on autolysis of certain components of the lens. Verhoeff and Lemoine (1922) conceived the condition as phako-anaphylactic or phakoallergic endophthalmitis, which they thought to be due to hypersensitivity of the lens-substance.

Duke-Elder (1940) is of the opinion that the increased intra-ocular pressure is probably ascribable to neurovascular reflexes elicited by irritating components of the lenses. That the matter of hypermature cataract may be able to cause such reflexes is suggested by the work of Friedenwald (1930) who showed that the permeabiltty of the capsule of the lens is increased in cataract. Strangely enough, these cases have received but little attention in the standard manuals of ophthalmology.

We have seen as many as ten cases at the clinic in the last 4 years (Table III, opposite). As to treatment there is little agreement. Rychener (1950) urges early operation by the intracapsular method, but if the capsule cannot be caught, the operation should be done by the method of Smith or with the erisophake. If the capsule ruptures, the nucleus of the lens can be removed and the rest of the capsule washed out with an irrigator.

I recommend early operation, particularly in order to overcome the secondary glaucoma, which is usually the only way to control intra-ocular pressure. Of course, we first try for some hours to lower the intra-ocular 
TABLE III

HYPERMATURE CATARACT WITH IRITIS AND/OR SECONDARY GLAUCOMA

\begin{tabular}{|c|c|c|c|c|c|c|c|}
\hline \multirow{2}{*}{ Case No. } & \multirow{2}{*}{ Vision } & \multirow{2}{*}{ Tension } & \multirow{2}{*}{ Cornea } & \multirow{2}{*}{$\begin{array}{l}\text { Aqueous } \\
\text { Flare }\end{array}$} & \multirow{2}{*}{ Operation } & \multicolumn{2}{|c|}{ Result } \\
\hline & & & & & & Vision & Tension \\
\hline 1 & $\begin{array}{l}\text { Perception } \\
\text { of Light }\end{array}$ & 40 & cloudy & +++ & $\begin{array}{l}\text { Extracapsular } \\
\text { extraction }\end{array}$ & 0,7 & normal \\
\hline 2 & $\begin{array}{l}\text { Perception } \\
\text { of Light }\end{array}$ & $45-51$ & cloudy & +++ & $\begin{array}{c}\text { Extracapsular } \\
\text { extraction }\end{array}$ & $0,5-6$ & normal \\
\hline 3 & $\begin{array}{l}\text { Perception } \\
\text { of Light }\end{array}$ & 45 & cloudy & + & $\begin{array}{c}\text { Extracapsular } \\
\text { extraction }\end{array}$ & 0,1 & normal \\
\hline 4 & $\begin{array}{c}\text { Perception } \\
\text { of Light }\end{array}$ & 53 & cloudy & $++t$ & $\begin{array}{l}\text { Extracapsular } \\
\text { extraction }\end{array}$ & $\begin{array}{l}\text { Perception } \\
\text { of Light }\end{array}$ & sub-normal \\
\hline 5 & $\begin{array}{c}\text { Perception } \\
\text { of Light }\end{array}$ & $25-28$ & clear & + & $\begin{array}{l}\text { Extracapsular } \\
\text { extraction }\end{array}$ & 0,7 & normal \\
\hline 6 & $\begin{array}{l}\text { Perception } \\
\text { of Light }\end{array}$ & 51 & clear & & $\begin{array}{c}\text { Extracapsular } \\
\text { extraction }\end{array}$ & 0,4 & normal \\
\hline 7 & $\begin{array}{l}\text { Perception } \\
\text { of Light }\end{array}$ & 15 & clear & $++t$ & $\begin{array}{l}\text { Intracapsular } \\
\text { extraction }\end{array}$ & 1,0 & normal \\
\hline 8 & $1 / 60$ & 48 & cloudy & +++ & $\begin{array}{l}\text { Intracapsular } \\
\text { extraction }\end{array}$ & $\begin{array}{ll}0, & 4 \\
0, & 5\end{array}$ & normal \\
\hline 9 & $\begin{array}{c}\text { Perception } \\
\text { of Light }\end{array}$ & $22-25$ & clear & ++ & $\begin{array}{c}\text { Intracapsular } \\
\text { extraction }\end{array}$ & 0,6 & normal \\
\hline 10 & $\begin{array}{l}\text { Perception } \\
\text { of Light }\end{array}$ & 36 & (cloudy) & ++ & $\begin{array}{l}\text { Intracapsular } \\
\text { extraction }\end{array}$ & & \\
\hline
\end{tabular}

tension with antiglaucomatous remedies. In operating, I generally proceed as follows:

If the capsule is definitely or very probably ruptured I make a small incision with the lancet, and then rinse or aspirate any remains of the cataract matter. The nucleus is often so small that the short incision is sufficient to permit its removal. Otherwise the incision is extended as much as may be necessary to extract the nucleus.

If the lens is probably intact I do an intracapsular extraction, but the large incision involves a certain risk if the intra-ocular pressure is high and cannot be reduced. Corneoscleral sutures should be used.

If it is difficult to decide whether or not the capsule is intact, I prefer the first method.

BONE-FREE RADIOGRAPHY.- This method is so useful in the removal of nonmagnetic or only slightly magnetic foreign bodies from the eye that its value should be more widely known. We all know the description of bone-free radiography by Vogt (1921), which, however, permits inspection only of the anterior of the eye. Franceschetti (1934) was the first to use an operative radiography of the eyeball; but his pictures hardly suggested that the bulb could be exposed sufficiently for technically satisfactory bone-free radiography.

The method we use is roughly as follows:

Canthotomy is done and the half of the conjunctiva, from 12 to 6 o'clock, is detached at the limbus. After temporary resection of one or more of the straight eye muscles, as circumstances may require, sutures are fastened in the margin of the fascia of Tenon, further and further back so that the fascia can be distended and the bulb thereby displaced anteriorly. It is surprising how much of the eye then becomes available for radiography. It is the same method as I use in detachment operations when it is necessary to do diathermy over a hole located far back in the retina. A piece of film (Agfa) in a rubber sleeve moistened with saline, is introduced epibulbarly and as far back as possible, often right back to 
the posterior pole of the bulb. The exposure is made with the $x$-ray tube at right angles to the film. The eyeball can thus be observed right back to the posterior pole (Figs 1 and 2).

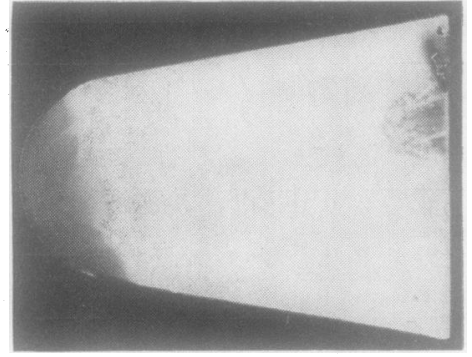

FIG. 1.-Bone-free radiograph according to Vogt.

This method is particularly valuable for the detection and removal of foreign bodies that cannot be removed by ordinary techniques. If an ordinary scout film can reveal any foreign body, it is possible by the usual methods to locate its approximate position. The film must be placed as close as possible to that part of the eyeball where the foreign body is suspected.

One or more indicators (we use broken-off tips of fine needles) are inserted in the sclera at the desired position. It is recommended to have them at right angles in order to facilitate recognition on the films. Radiographs are also made at right angles to one another.

The film shows whether the foreign body is located near any of the needles. If not, new indicators are inserted until new radiographs have shown that the foreign body is close to them. Recently we also inserted a Pischel needle through a diathermized spot; this gives a better idea of the depth of the foreign body. After the foreign body has been accurately located the sclera is surface-diathermized and an incision is made until the choroid is exposed. The foreign body is then often visible in the gaping wound. It is easier to detect the foreign body if the eyeball is transilluminated: the shadow of the foreign body is then seen in the wound. (Figs 3 and 4, opposite).

We have used this method in 36 cases of non-magnetic foreign bodies or foreign bodies that could not otherwise be removed (Table IV, opposite).

Behrmann's locator was found not effective with such small foreign bodies as those occurring in the eye. As far as I know, this is the most reliable way of removing non-magnetic foreign bodies, and it is also useful for removing iron foreign bodies that have been in the eye for some time, so that they have begun to rust, to lose their magnetism, and to become adherent to the scar tissue. I would even go so far as to say that it is unwise to try to extract 


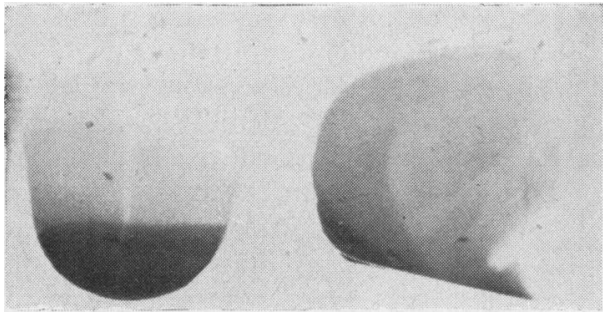

FIG. 3.-Radiographs (natural size) of surgically exposed eyeball taken at right angles to one another. Indicators fastened in the sclera were found to be more than $5 \mathrm{~mm}$. from the iron fragment. With the guidance of these radiographs the indicators were moved.

TABLE IV

THIRTY-SIX CASES OF INTRA-OCULAR FOREIGN BODIES LOCATED BY OPERATIVE BONE-FREE RADIOGRAPHY

\begin{tabular}{|c|c|c|c|c|}
\hline Foreign Bodies & $\begin{array}{l}\text { Number } \\
\text { of Cases }\end{array}$ & $\begin{array}{l}\text { Foreign Bodies } \\
\text { Located and } \\
\text { Extracted }\end{array}$ & Resultant Vision & $\begin{array}{c}\text { Not } \\
\text { Extracted }\end{array}$ \\
\hline $\begin{array}{l}\text { Iron, not removable } \\
\text { by ordinary methods }\end{array}$ & 26 & 19 & $\begin{array}{l}7, V=1 \\
5, V=0,2-0,5 \\
7, \text { hand movements or less }\end{array}$ & 7 \\
\hline Other metals $\ldots \quad \ldots$ & 10 & 6 & $\begin{array}{l}3, V=1 \\
1, V=\text { perception of light } \\
2 \text {, cataract not operated } \\
\text { on, later enugleated }\end{array}$ & 4 \\
\hline $\begin{array}{lll}\text { Total } \ldots & \ldots & \ldots\end{array}$ & 36 & 25 & 25 & 11 \\
\hline
\end{tabular}

even magnetic foreign bodies without first locating them exactly.

For example, in one case we located an iron foreign body but did not insert the locators close enough. I relied on the belief that a magnet introduced through the wound would extract the iron foreign body, but the operation failed, and later the eye was enucleated. Hardly one millimetre from the wound incision in the sclera lay the foreign body surrounded by a little exudate and scar tissue. It was still magnetic, and if it had been located with greater accuracy, I am sure I could have removed it successfully.

RADIO THERAPY.-Technical advances have increased our interest in the radiological treatment of certain eye diseases. Inspired by the work of Guyton and Reese (1948) and Iliff (1951) and in collaboration with the radiological clinic (Dr. Ebenius), we approached the treatment of certain eye diseases from a new angle. This applies in particular to vernal conjunctivitis, Eales's disease, and diabetic retinopathy.

The value of radiological therapy in vernal conjunctivitis was stressed by Kumer and Sallmann (1929) and has since been confirmed by a number of other workers. In the treatment of vernal conjunctivitis we first used only beta-radiation by Iliff's method, but on account of objections raised by our radiologists we have now to a certain extent dropped it. 
The Burnam applicator used by Iliff consists of a glass bulb containing radon, a product liberated on disintegration of radium. The bulb has a window $4 \mathrm{~mm}$. in diameter.

The American method of measuring the dose in gram-seconds has proved valueless, chiefly because the wall of the glass bulb serving as a filter varies considerably in thickness. According to our radio-physicists this variation is sometimes as much as 100 per cent. Our measurements are based on biological comparisons between the effect (in the form of the skin reaction) of surface contact radio therapy and radon treatment. Radon does not emit only beta rays, but gamma rays are also soon emitted. At Lund, investigation of the amount of gamma-radiation showed that these rays expose the radiologist to unnecessary risk. The small aperture of the Burnham applicator makes it necessary to move the instrument from one place to another when treating large fields, which involves the risks of overlapping and lack of uniformity. Finally, the effect of beta-radiation is too superficial for massive excrescences.

We therefore use contact $x$-ray therapy in selected cases. It is thus possible to obtain a more uniform radiation of a larger area, and more accurate doses may be given. Contact surface $x$-ray therapy also produces a deeper effect, which is particularly useful in severely hypertrophic conjunctivae, but is not desirable in the treatment of corneal and limbal changes, where beta-radiation with radon is preferable.

When we use radon the applicator is shifted over the entire surface to be treated. Treatment is given at 2-week intervals for 6-12 weeks. The total-surface-dose per treatment varies between 4,000 and 5,000r. Only in exceptional cases do we use larger doses.

Contact $x$-ray therapy is given with a Philips apparatus at a distance of $4 \mathrm{~cm}$., 2,000r being delivered at every application. The maximum single dose is 7,000 r. The eyeball is protected by a lead screen. In treating tarsal changes $x$-ray contact therapy gives better results.

We have treated altogether eleven cases of vernal conjunctivitis. Seven patients made a complete recovery and the rest were given considerable relief: Recovery was said to be complete if the patients were symptom-free, the characteristic tarsal changes had disappeared, and the conjunctivae had become pale, smooth, even, and without secretion. Now and then small telangiectases were seen. The patients were followed-up for 2 to 8 years. One remarkable case is described below.

A 48-year-old woman had a 12 years' history. The disease was practically unilateral. In addition to the characteristic but not advanced changes of the tarsus, there was a tumour-like formation in the limbus. This formation gradually increased in size. Histological examination showed hyperplasia of the stroma, increased connective tissue, and numerous round cells and eosinophilic cells: a typical allergic reaction of the tissue. The picture thus coincided with that of vernal conjunctivitis. The patient was treated with $x$-ray contact radiation in 1944 and $1945,8,000 \mathrm{r}$ on the interior surface of the upper eyelid, and in 1950 she received 8,000r radon radiation of the cornea. The tumour disappeared completely, and the cornea showed only a vascularized macula. Visual acuity improved from counting fingers at $2 \mathrm{~m}$. to $4 / 10$ (Fig. 5).

The results we have obtained will be.obvious from coloured illustrations of a few cases (Colour Plate 1-5, opposite).

Colour Plate 1 ( $a$ and $b$ ).-Left eye, vernal conjunctivitis treated with $x$-ray contact radiation $5,000 \mathrm{r} / 8$ weeks.

$2(a$ and $b)$. - Same patient, right eye, radon treatment 7,500r/10 weeks.

$3(a$ and $b)$.- - Vernal conjunctivitis, $x$-ray contact radiation $5,000 \mathrm{r} / 7$ weeks, and $2,000 \mathrm{r} 4$ months later.

$4(a$ and $b$ ). - Vernal conjunctivitis, $x$-ray contact radiation $4,000 \mathrm{r} / 7$ weeks.

$5(a$ and $b)$. - Vernal conjunctivitis with tumour-shaped corneal lesion treated with radon $8,000 \mathrm{r} / 6$ months. 

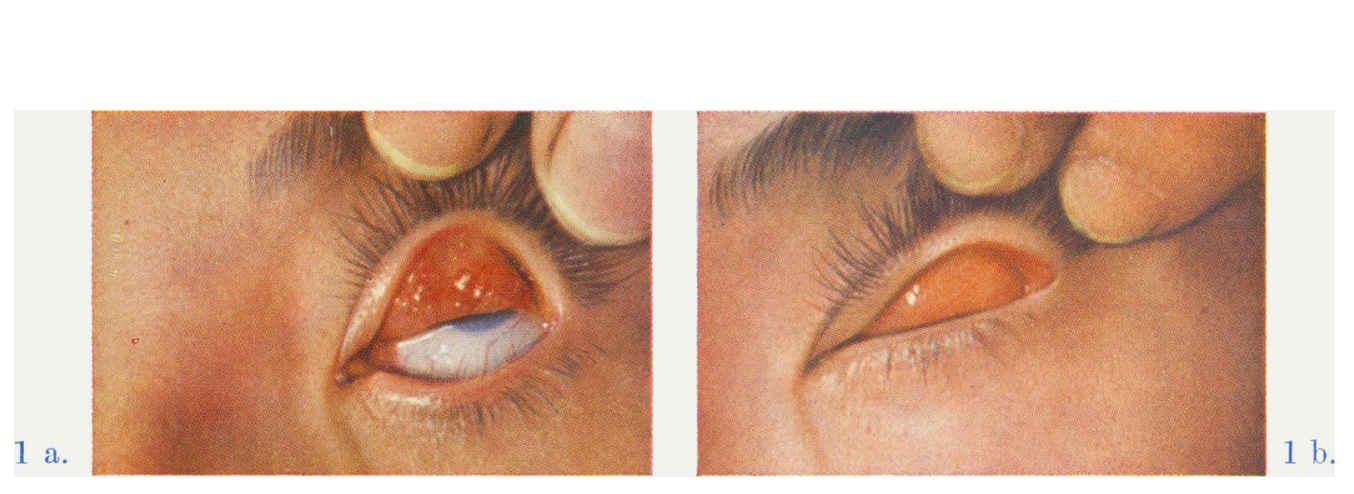

政

3 a.
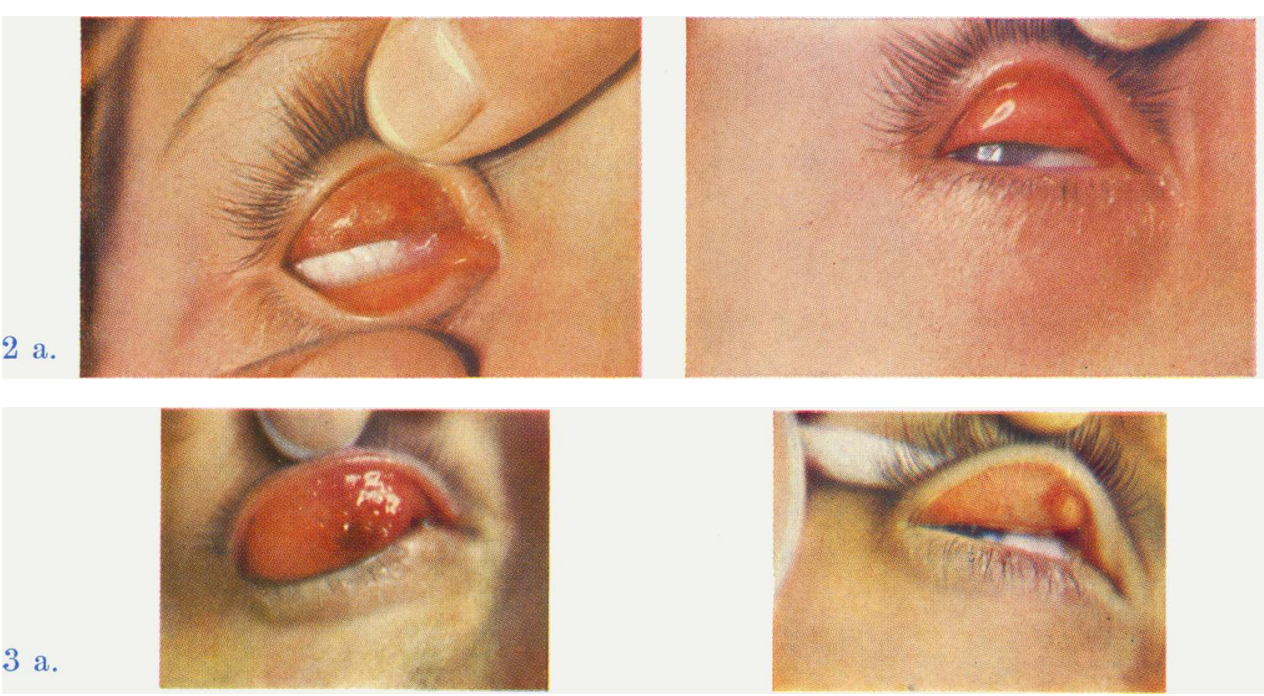

2 b.
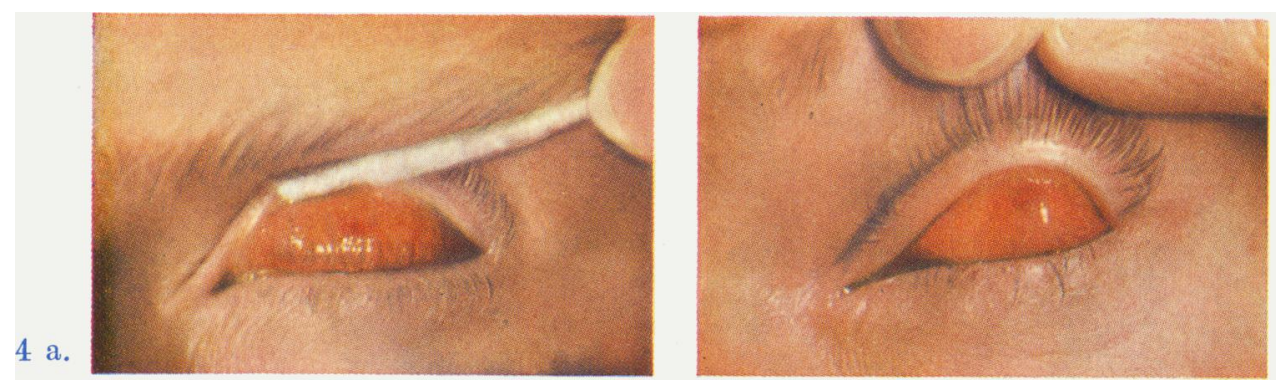

$3 \mathrm{~b}$.
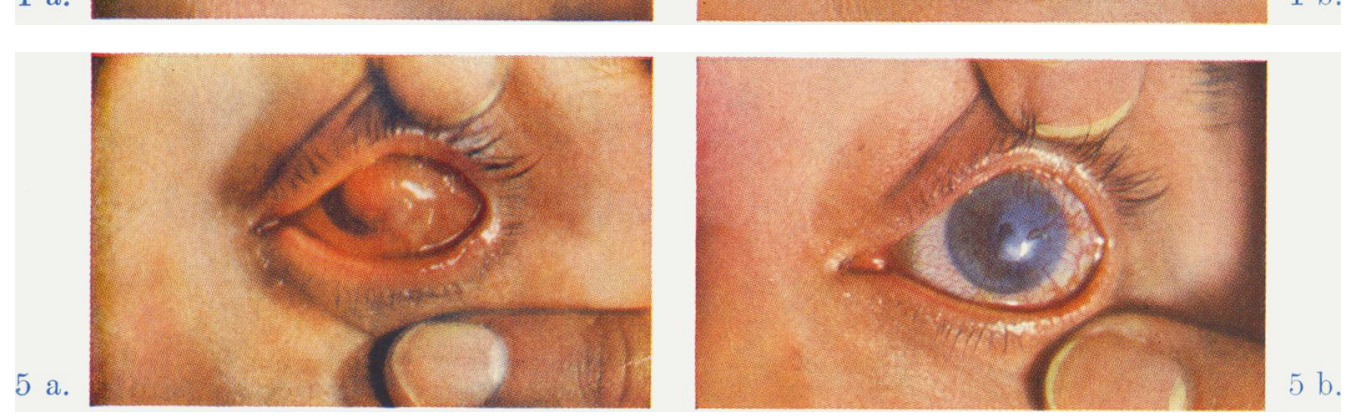

4 b.

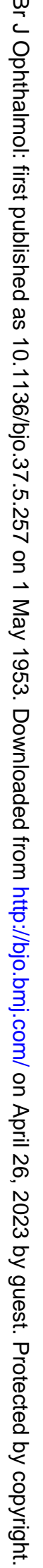


ORBITAL IMPLANTS.-For the last 30 years I have been trying different kinds of orbital implants in the hope of getting a better bed for the artificial eye. The best material we have so far found for this purpose is tantalum. We use a very simple type of implant: a ball $12 \mathrm{~mm}$. in diameter, weighing $1.7 \mathrm{~g}$., and perforated with many holes (Fig. 5). The straight eye muscles are fastened into the holes and the entire ball is carefully covered with the fascia of Tenon. The fascia and the conjunctiva are then sutured. The patient generally receives penicillin postoperatively for a few days. We have used the method mostly for children and younger patients. We are not quite satisfied with it, because, as with other types, the implant is lost in four cases out of eleven. This may, however, be due to the fact that in the beginning we did not sufficiently cover the implant with fascia of Tenon, which is absolutely necessary if the operation is to be successful. I agree entirely with Choyce (1952) who stressed how necessary it is to bury the implants.

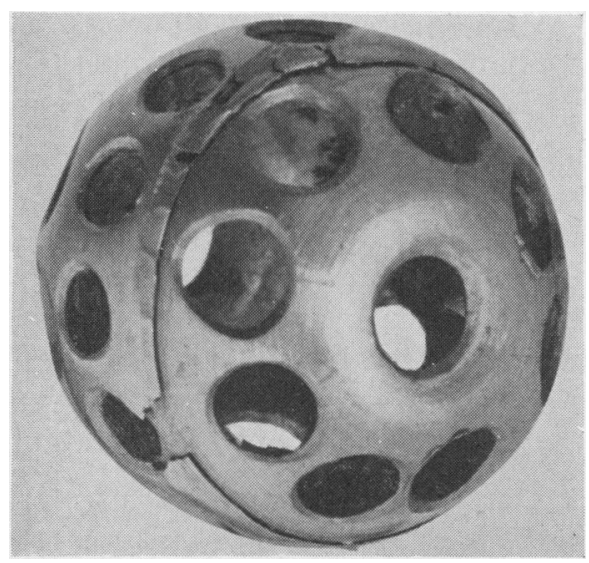

FIG. 5.-Tantalum implant, $12 \mathrm{~mm}$. diameter.

Retinal Detachment.-I have only changed a few details in my operative method for detachment of the retina since I first described the technique in 1930. I still use diathermy, or rather endothermy with a ball electrode of exactly the same type as before. In the location of the hole I use the needles recommended by Pischel. A varying number of these needles are inserted trans-sclerally in the suspected area of the hole before the commencement of surface diathermy treatment. These needles, which are mounted in a special holder, are then charged with the electric current. It is almost always possible to recognize the inserted needles by indirect ophthalmoscopy. After having located the hole in this manner, surface diathermy is done. This is generally limited to an area corresponding to the retinal hole and its immediate surroundings, and the strength of the current is adjusted by trial being gradually increased until the sclera shows a slightly grey, discoloured spot and an obvious slight flattening, like a contraction of the scleral surface. Nowadays the subretinal fluid is no longer drained by means of scleral trephining but by punctures made with a diathermy needle behind the hole in the retina and at the site where the detachment is most prominent. Like Pischel, I now aspirate the subretinal fluid with the aid of a small sucker with the suction cup, placed over a diathermized perforation. Only if the detachment is very high and will not respond to rest in bed do I inject air into the vitreous body. 
In cases where the retinopathy is very limited, the limitation of the endothermy to the immediate surroundings of the retinal hole has certain advantages. On the other hand, it must be remembered that sometimes a fairly large area of the retina, or even the whole, may be involved. In such cases, limited endothermy may be less successful, because recurrences are likely to appear at the sites of the adhesions produced by endothermy, and the diseased retina may easily burst. In the many cases of retinopathy caused by obscure cyclitic or chorioretinal lesions, more extensive endothermy is probably preferable; it is sometimes possible by the present method to seal the retinal hole and make the retina adhere to the choroid, but we cannot cure retinopathy, which must be the more important aim. Unfortunately we know very little about pathological changes in the anterior part of the fundus, but perhaps the intra-ocular endoscope suggested by Butterworth and Bignell (1952) will help to throw light on their nature. The most important problem to be solved by investigators of retinal detachment is the discovery of the nature of the underlying retinopathy and this is more important than improved surgical methods of treatment. The following case was unexpectedly successful.

A one-eyed 83-year-old man had an aphakic eye and total detachment. On the 3rd day after operation he became confused, left his bed, and had the old idea that he should carry it away with him. He was transferred to a clinic for psychiatry. When I saw him 6 weeks later he had a perfect reattachment and visual acuity was 2/10.

\section{REFERENCES}

BUtTERWORTH, R. F., and BignelL, J. L. (1952). British Journal of Ophthalmology, 36, 217. CHOYCE, D. P. (1952). Ibid, 36, 123.

DUKE-ELDER, S. (1940). "Text-book of Ophthalmology", vol. 3, p., 2133. Kimpton, London. FRANCESCHETTI, A. (1934). Bull. Soc. franc. Ophtal, 47, 230.

FriedenWALd, J. S. (1930). Arch. Ophthal., Chicago, 3, 182.

GIFFORD, H. (1927). Ibid., 56, 457.

GuYTON, J. S., and REESE, A. B. (1948). Ibid, 40, 389-412.

ILIFF, C. E. (1951). "XVI Concilium Ophthalmologicum, 1950 Britannia Acta ”, vol. 2, p. 1357. KnAPP, A. (1947). Arch. Ophthal. Chicago, 38, 1.

Kumer, L., and Sallmann, L. (1929). "Die Radiumbehandlung in der Augenheilkunde". Springer, Vienna.

PaufiQue, L. (1952). Personal communication.

RiDLEY, H. (1952). British Journal of Ophthalmology, 36, 113.

RYCHENER, R. O. (1950). Amer. J. Ophthal,, 33, 1666.

LARSSON, S. (1941). Acta ophthal. Kbh., 19, 1.

VerhoefF, F. H., and Lemoine, A. N. (1922). Amer. J. Ophthal., 5, 737. 